\title{
Reading strategies used by Grade 9 English Second Language learners in a selected school
}

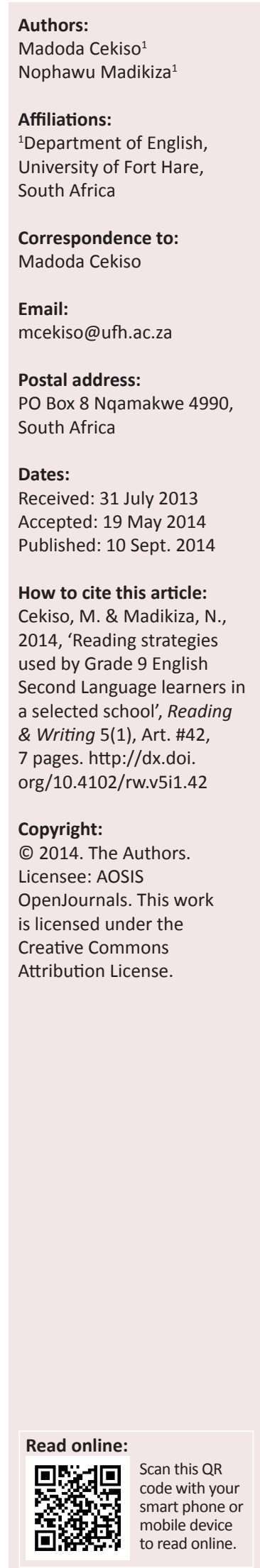

Knowledge of the reading strategies used by English Second Language learners can help teachers to plan appropriate lessons and apply relevant methods of teaching reading in order to enhance learners' reading comprehension. The main objective of this study was to investigate the reading strategies used by Grade 9 English Second Language (ESL) learners and also to establish if there was any significant difference between perceived strategy use and gender. The respondents (192) were all ESL learners in Grade 9 in 2011 in a selected school. The study employed a quantitative research method. The study used convenience sampling on a group of 192 Grade 9 learners. The data collected through questionnaires was analysed by means of the Statistical Package for Social Sciences (SPSS) software. The findings revealed that the learners did not employ a wide range of reading strategies. The results further indicated that there was no significant difference between boys and girls in terms of strategy use. Based on the above findings several suggestions were made to help teachers improve their teaching and help learners improve their reading comprehension and also about possible areas for future research.

\section{Introduction}

The literature has shown that awareness of the reading process and reading strategy use of readers can improve learners' reading comprehension (Porter 2010; Wessels 2007). According to Tercanlioglu (2004:12), reading strategies are specific actions, behaviours, steps or techniques learners use to improve their progress in comprehending, internalising and using a second language. The literature reveals that in order to improve reading proficiency and design reading skills development programmes in an informed manner, educators' knowledge of their learners' knowledge about reading and reading strategies must be increased (Sheorey \& Mokhtari 2001:439). Thus, educators' knowledge about the reading strategies used by their learners is important for planning relevant lessons and also for making an informed decision about whether to teach reading strategies explicitly or implicitly. Such a decision could be taken in order to develop the learners' reading comprehension.

Many studies conducted in South Africa and in other countries reveal that reading with comprehension is difficult for learners (Dreyer \& Nel 2003; Porter 2010; Sheory \& Mokhtari 2001; Wessels 2007). Such studies reveal that this problem manifests itself at primary level and secondary level, as well as at university level. In a South African context, the high failure rate at matric (Grade 12) level is partly ascribed to the lack of reading comprehension, which is associated with the use of ineffective and inefficient reading strategies (Pretorius 2002). Some studies reveal that learners find it difficult to understand the examination questions and end up making wrong guesses that lead to incorrect answers (Madikiza 2011:3). In addition, Van Wyk (2001) points out that learners present low levels of reading strategy knowledge and lack the strategies needed to successfully comprehend expository texts; hence, they often select ineffective and inefficient strategies with little strategic intent. Subsequently, the use of a range of reading strategies has been seen as a solution in order to empower learners with the relevant tools to comprehend the printed text. In the literature there is a strong debate about the choice and use of reading strategies according to gender. Such studies have produced contradicting results. For example, in a study conducted by Monos (2004:149), female learners reported higher usage of reading strategies than male learners in all categories of strategies. However, a study conducted by Tercanlioglu (2004:14) found that boys were using more strategies than girls. Therefore, the current study seeks to make a contribution by exploring the reading strategies used by both boys and girls amongst the Grade 9 learners in a particular school and make recommendations on how the learners' reading strategy use could be improved or stretched so as to develop their reading comprehension.

\section{Purpose of the study}

The purpose of this study was to find out what reading strategies learners in the selected school used, and with what frequency, to approach English Second Language (ESL) texts and whether 
there were differences in strategy choice between boys and girls. Specifically, the study sought to address the following research questions:

1. What type and frequency of use of reading strategies do the learners use before, during and after reading?

2. Is there any significant difference between the perceived strategy use of girls and boys?

\section{Theoretical perspective}

Strategic awareness and monitoring of the comprehension process are critically important aspects of skilled reading (Sheory \& Mokhtari 2001). Such awareness and monitoring is often referred to in the literature as 'metacognition', which entails knowledge of strategies for processing texts, the ability to monitor comprehension and the ability to adjust strategies as needed (Euerbach \& Paxton 1997:239). According to Sheory and Mokhtari (2001:444), it is the combination of conscious awareness of the strategic reading process and the actual use of reading strategies that distinguishes skilled readers from unskilled readers. The literature reveals that successful reading strategy use is dependent on whether a strategy is employed metacognitively (Carrell 1989; Jimenez 1996). In addition, (Mokhtari \& Reichard 2004:379) point out that these less successful learners, who are often unaware of their own cognitive process, must be helped to acquire and use the reading strategies that have been identified to be successful. Similarly, this study sought to identify the current strategies used by learners and introduce them to a repertoire of reading strategies in order for them to comprehend a wide range of printed texts. Sloat, Beswick and Willms (cited in AD-Heisat 2009) state that failure to learn reading at the primary level may cause a learner to lack the ability to read well. Sloat et al. further point out that learners with limited literacy skills may develop poor self-esteem, lack motivation and display behavioural and academic problems, thus causing them to be alienated from the regular curriculum (see AD-Heisat 2009). Therefore, reading comprehension is a critical component of effective reading instruction for learners even at an early stage (Begeny et al. 2010).

According to Pretorius (2002:99), a fundamental feature of academic underperformance in South Africa is poor reading ability. The results of her study show that the learners who fail are those who obtain low marks on reading tests and attain comprehension levels of less than $4.5 \%$. This study sought to establish the Grade 9 learners' current use of reading strategies in the selected school. This could assist the learners to cope with their reading at higher levels. Pretorius (2002:98) states that the skill of reading becomes more demanding as learners go up the education ladder, whilst the gap between skilled and unskilled readers widens. Noor (2010:67) concurs with Pretorius by stating that in any academic or higher learning context, the ability to read is a crucial skill as it requires learners to interact with and process information from texts. Noor further points out that many first-year university students, specifically second language learners, who enter institutions of higher learning are unprepared for the reading demands placed upon them and they encounter difficulties. Thus, learners' awareness and use of reading strategies is important for academic success. This concern is also echoed by Dreyer and Nel (2003:168), who point out that many South African students who register for undergraduate studies each year are underprepared for university education. Therefore, it is important to develop the reading skills of the learners as early as primary level so as to equip them with reading strategies to manage the academic demands of university education. In addition, Oxford (1990:2) points out that creating awareness, attention, intentionality and control of reading strategies are amongst the most useful contributions that teachers can make to develop their learners' comprehension ability.

Research into reading strategies reveals that there are three classifications of reading strategies. These are pre-reading strategies, during-reading strategies and post-reading strategies. According to Al-Issa (2006), pre-reading strategies help one to identify the reading demands, activate what one knows about the topic and anticipate what will be read. The pre-reading stage is the crucial stage for building background knowledge. According to Saricoban (2002:150), pre-reading strategies attempt to improve learners' interest in the topic and motivate them, provide some predicting or guessing activities for the passage, prepare the learners for the context of the reading and build a bridge between the reading passage and the learners' background and interest. The second category of reading strategies, during-reading, helps learners to cope with problematic and greyer areas of the text such as identifying the main areas of the text (AD-Heisat 2009). Some examples of the during-reading activities identified by AD-Heisat (2009) and Flowerdew and Peacock (2001) are guessing word meaning by using clues, word information clues or cognates, scanning and skimming for specific pieces of information. The third category, post-reading, helps learners deepen their understanding of their comprehension of the content, build further connections and expand their prior knowledge of the subject matter (AD-Heisat 2009). In addition, Cekiso (2007) points out that post-reading strategies help learners to draw conclusions and make judgements and generalisations. Some examples of post-reading strategies include evaluating text purpose, confirming predictions, summarising, reflecting, questioning and connecting materials to one's own life (Christen \& Murphy 1991).

Tercanlioglu (2004:16) states that the consistent results of studies have shown that gender plays an important role in strategy choice. In a study conducted by Monos (2004:150) amongst Hungarian university students, the findings indicated that female students reported higher usage of reading strategies than male students in all categories and they seemed to be more conscious strategy users than male students. The results of Tercanlioglu's study, conducted on Turkish students, were not consistent with those of Monos. Her study revealed that boys were using more strategies that girls. She further points out that a possible explanation for this result may be that in the male-dominated Turkish society 
female students may have lower self-esteem in reporting the strategies they use.

\section{Problem statement}

Poor reading comprehension amongst ESL learners is well documented in both national and international studies (AD-Heisat 2009; Cekiso 2012; Dreyer \& Nel 2003; Monos 2004; Pretorius 2002). Research conducted in South Africa indicates that many South African students who register for undergraduate studies each year are underprepared for university education. It also shows that many of these students also have low reading ability (Dreyer \& Nel 2003:167). The same sentiment is echoed by Van Wyk (2001:126), who states that learners present low levels of reading strategy knowledge and lack the strategies needed to successfully comprehend expository texts. This is a cause for concern as reading comprehension forms the pillar of the learning process. Learning without comprehending would be a futile exercise and waste of time. This idea is supported by Pretorius (2002), who states that research findings in applied linguistics and reading research consistently show a strong correlation between reading proficiency and academic success at all ages, from primary school right through to university level. Therefore, knowledge of reading strategies is important for both teachers and learners and interventions based on that knowledge are likely to be meaningful and beneficial for both parties.

\section{Rationale of the study}

Since reading is considered the most important skill in academic contexts (Grabe 1991) and reading strategies are crucial for efficient reading comprehension (Carrell 1989), it is therefore important for teachers to prepare their learners to become competent readers by raising their awareness and use of reading strategies. It is assumed that such knowledge can help learners to differentiate between effective and ineffective reading strategies. In addition, teacher knowledge of the reading strategies used by their learners is likely to help them gain insights into effective strategy instruction. Applying the findings of this study is likely to help 'struggling' readers to become high-ability readers.

\section{Research method}

This study used a quantitative research method, which is a process that is systematic and objective in its ways of using numerical data from a selected subgroup of a universe (or population) to generalise the findings to the universe that is studied (Maree 2008). The target population comprised Grade 9 learners who were all isiXhosa speakers studying English as a second language (ESL) in the Mthatha district of the Eastern Cape. A convenience sample of 192 learners (all Grade 9 learners in a single selected school) was chosen by means of convenience sampling. The sample constituted 80 boys and 112 girls.

\section{Instrumentation}

The instrument used to collect data in this study was only a questionnaire. Many studies have relied only on questionnaires in order to identify strategy use as well as frequency of strategy use by learners (Alhaqbani \& Riazi 2012; Poole 2009; Zhang \& Wu 2009). Data on learners' awareness and use of reading strategies before, during and after reading was collected from one selected school. The researchers used a standardised reading strategies questionnaire inventory developed by Oxford (1990) to determine learners' use of reading strategies. The researchers rearranged the reading strategies in this questionnaire so as to focus on pre-reading, during-reading and post-reading strategies. The subjects identified the reading strategies they employed by rating how well a certain statement described them. The questionnaire had 34 items (7 for pre-reading strategies, 18 for duringreading and 8 for post-reading strategies). Taking into consideration the ESL proficiency level of the participants, it was decided that the questionnaire be administered in isiXhosa, the mother tongue of the participants and thus the language they were most proficient in and comfortable with. A similar technique was used by Zhang and Wu (2009), who translated the English version of their questionnaire into Chinese, which was the native language of their learners. The idea was to guarantee successful data collection and avoiding comprehension difficulties that participants might encounter when given the English version. In the current study, the questionnaire was translated to isiXhosa by one of the local university lecturers, who holds a doctoral degree in translation and is highly proficient in both English and isiXhosa. Her mother tongue is isiXhosa, which is also the mother tongue of the participants. The survey questionnaire used a five-point Likert scale:

1. never true for me

2. usually not true for me

3. somewhat true for me

4. usually true for me

5. always or almost always true for me.

\section{Data analysis}

The data from the questionnaire was analysed using the Statistical Package for Social Sciences (SPSS) software. This method of analysis required that data be coded before being captured. The Chi-square test was used to examine the relationship or association between girls' and boys' strategy choices and also to answer questions on the frequency of reading strategies employed by Grade 9 learners whilst reading texts.

\section{Findings and discussion}

The objective of this study was to investigate the reading strategies employed by the Grade 9 learners in a selected school. The study also set out to discover if there was any significant difference between the perceived reading strategy use of boys and girls.

The reading strategies were grouped as pre-reading, duringreading and post-reading strategies. The researchers noted that there was a wide range of critical reading strategies 
for text comprehension that were not employed by the majority of learners. This was shown by the low frequency of some reading strategy use. Tsai, Ernest and Talley (2010:29) argue that strategy use has a positive influence on reading proficiency because skilled readers use more strategies in various categories than less-skilled readers do. This is a cause for concern as learners in the current study seemed not to use some key reading strategies at all. The results of the reading strategies questionnaire shown in Table 1 indicate that the Grade 9 learners were not using the majority of pre-reading strategies: the learners reported only using two out of seven reading strategies they were supposed to use in this category. The strategies that were used by the majority of learners were 'I look for important information in the text' and 'I try to draw on my knowledge of the subject to generate questions about the text'. The majority of the learners did not know how to skim the text or how to use knowledge of the subject to help them generate questions about the text; they did not know how to set goals and struggled to search out information relevant to the reading goals. Yet, the knowledge and application of the pre-reading strategies is important for text comprehension. Berrett (2011:69) uses the analogy of sport in order to stress the importance of the prereading strategies. She states that before playing a sport or doing other physical activity, it is important to warm up and prepare your body for the upcoming task. She further states that the same thing applies to the reading process as you need to warm up and prepare your mind for reading so that you can perform your best, get the most of it and increase your comprehension. The importance of pre-reading strategies is echoed by Williams (cited in Al-Issa 2006), who states that the pre-reading phase is the most important phase for building background knowledge and to help one to identify the reading demands. The findings of this study contradict the findings of a study conducted by Cekiso (2007:98), whose results indicated that Grade 11 learners reported using prereading strategies more than other strategies.

Table 2 reveals that during reading the learners were not using some important reading strategies that facilitate reading comprehension. Amongst such strategies are: summarising or paraphrasing as you read, jumping forward or backwards in the text to find important information, trying to underline when reading in order to remember the text and making notes in order to remember the text. The awareness and use of the during-reading strategies is emphasised by AD-Heisat (2009), who points out that these strategies help learners cope with problematic and greyer areas of the text such as identifying the main areas of the text, guessing word meaning by using context clues, word information clues or cognates, scanning and identifying topic sentences that contain the main idea of the paragraph. In addition, Cekiso (2007:77) states that duringreading activities help learners to self-monitor reading and also to focus on details or concepts that are relevant to the purpose of reading. The fact that the learners were less frequently using the strategy of summarising the text was a concern for the researchers as they observed that in many examination papers for Grade 9 learners there was a question on summarising a text. According to Dotwana (2009:65), summarising is an obvious reading habit as it is proper for one to summarise whenever one has read for easy understanding and for the sake of remembering a good fraction of the material read. In the during-reading category, only two reading strategies were used by the majority of learners: 'I distinguish between information that I already know and new information' and 'I note what I am interested in or bored by within the text'.

Table 3 indicates that during the post-reading stage the majority of the reading strategies were not used at all by the learners. The use of the post-reading strategies is emphasised by AD-Heisat (2009) when he points out that post-reading strategies help learners deepen their understanding of the content, build further connections, expand their prior knowledge of the subject matter, select, organise and use relevant information, draw conclusions and make judgements and generalisations. It is clear in the current study that learners cannot summarise the information

TABLE 1: Pre-reading strategies.

\begin{tabular}{|c|c|c|c|c|c|c|c|c|c|c|c|c|c|c|}
\hline \multirow[t]{2}{*}{ Statement } & \multicolumn{2}{|c|}{$\begin{array}{c}\text { Never or almost } \\
\text { never true for me }\end{array}$} & \multicolumn{2}{|c|}{$\begin{array}{l}\text { Usually not true } \\
\text { for me }\end{array}$} & \multicolumn{2}{|c|}{$\begin{array}{l}\text { Somewhat true } \\
\text { for me }\end{array}$} & \multicolumn{2}{|c|}{$\begin{array}{l}\text { Usually true } \\
\text { for me }\end{array}$} & \multicolumn{2}{|c|}{$\begin{array}{l}\text { Always true } \\
\text { for me }\end{array}$} & \multicolumn{2}{|c|}{ No response } & \multicolumn{2}{|c|}{ Total } \\
\hline & $f$ & $\%$ & $f$ & $\%$ & $f$ & $\%$ & $f$ & $\%$ & $f$ & $\%$ & $f$ & $\%$ & $f$ & $\%$ \\
\hline $\begin{array}{l}\text { 1. I briefly skim the text } \\
\text { before reading }\end{array}$ & 8 & 4.2 & 32 & 16.7 & 63 & 32.8 & 66 & 34.4 & 23 & 12 & - & - & 192 & 100 \\
\hline $\begin{array}{l}\text { 2. I look for important } \\
\text { information in the text }\end{array}$ & 3 & 1.6 & 16 & 8.3 & 52 & 27.1 & 71 & 37.0 & 48 & 25.0 & 2 & 1.0 & 192 & 100 \\
\hline $\begin{array}{l}\text { 3. I pay greater attention to } \\
\text { important information than } \\
\text { other information in the text }\end{array}$ & 5 & 2.6 & 11 & 5.7 & 48 & 25.0 & 73 & 38.0 & 51 & 26.6 & 4 & 2.1 & 192 & 100 \\
\hline $\begin{array}{l}\text { 4. I try to draw on my } \\
\text { knowledge of the subject to } \\
\text { help me understand what I } \\
\text { am reading }\end{array}$ & 2 & 1.0 & 16 & 8.3 & 55 & 28.6 & 52 & 27.1 & 65 & 33.9 & 2 & 1.0 & 192 & 100 \\
\hline $\begin{array}{l}\text { 5. I use my knowledge of } \\
\text { the subject to generate } \\
\text { questions about the text }\end{array}$ & 14 & 7.3 & 27 & 14.1 & 53 & 27.6 & 54 & 28.1 & 44 & 22.9 & - & - & 192 & 100 \\
\hline 6. I set goals for reading & 13 & 6.8 & 20 & 10.4 & 68 & 35.4 & 61 & 31.8 & 31 & 16.1 & 1 & 0.5 & 192 & 100 \\
\hline $\begin{array}{l}\text { 7. I search out information } \\
\text { relevant to my reading goals }\end{array}$ & 41 & 21.4 & 50 & 26.0 & 52 & 27.1 & 34 & 17.7 & 15 & 7.8 & - & - & 192 & 100 \\
\hline
\end{tabular}

f, frequency. 
TABLE 2: During-reading strategies.

\begin{tabular}{|c|c|c|c|c|c|c|c|c|c|c|c|c|c|c|}
\hline \multirow[t]{2}{*}{ Statement } & \multicolumn{2}{|c|}{$\begin{array}{l}\text { Never or almost } \\
\text { never true for } \\
\text { me }\end{array}$} & \multicolumn{2}{|c|}{$\begin{array}{l}\text { Usually not true } \\
\text { for me }\end{array}$} & \multicolumn{2}{|c|}{$\begin{array}{l}\text { Somewhat true } \\
\text { for me }\end{array}$} & \multicolumn{2}{|c|}{$\begin{array}{l}\text { Usually true } \\
\text { for me }\end{array}$} & \multicolumn{2}{|c|}{$\begin{array}{l}\text { Always true } \\
\text { for me }\end{array}$} & \multicolumn{2}{|c|}{ No response } & \multicolumn{2}{|c|}{ Total } \\
\hline & $f$ & $\%$ & $f$ & $\%$ & $f$ & $\%$ & $f$ & $\%$ & $f$ & $\%$ & $f$ & $\%$ & $f$ & $\%$ \\
\hline $\begin{array}{l}\text { 1. I try to relate the important } \\
\text { points in the text to one } \\
\text { another in an attempt to } \\
\text { understand }\end{array}$ & 9 & 4.7 & 30 & 15.6 & 61 & 32.8 & 63 & 32.8 & 26 & 13.5 & 2 & 1.0 & 192 & 100 \\
\hline $\begin{array}{l}\text { 2. I reconsider and revise my } \\
\text { prior questions about the text's } \\
\text { content }\end{array}$ & 17 & 8.9 & 40 & 20.8 & 58 & 30.2 & 49 & 25.5 & 26 & 13.5 & 2 & 1.0 & 192 & 100 \\
\hline $\begin{array}{l}\text { 3. I reconsider and revise my } \\
\text { background knowledge about } \\
\text { the subject based on the text }\end{array}$ & 9 & 4.7 & 24 & 12.5 & 53 & 27.6 & 56 & 29.2 & 50 & 26.0 & - & - & 192 & 100 \\
\hline $\begin{array}{l}\text { 4. When information critical to my } \\
\text { understanding of the text is not } \\
\text { directly stated, I try to infer that } \\
\text { information from the text }\end{array}$ & 18 & 9.4 & 36 & 18.8 & 70 & 36.5 & 50 & 26.0 & 17 & 8.9 & 1 & 0.5 & 192 & 100 \\
\hline $\begin{array}{l}\text { 5. I try to determine the meaning } \\
\text { of unknown words that seem } \\
\text { critical to the meaning of the } \\
\text { text }\end{array}$ & 14 & 7.3 & 19 & 9.9 & 44 & 22.9 & 51 & 26.6 & 64 & 33.3 & - & - & 192 & 100 \\
\hline $\begin{array}{l}\text { 6. I summarise or paraphrase the } \\
\text { material that I am reading in } \\
\text { order to remember the text }\end{array}$ & 33 & 17.2 & 46 & 24.0 & 57 & 29.7 & 32 & 16.7 & 22 & 11.5 & 2 & 1.0 & 192 & 100 \\
\hline $\begin{array}{l}\text { 7. I evaluate the text to determine } \\
\text { whether it contributes to my } \\
\text { knowledge or understating of } \\
\text { the text }\end{array}$ & 8 & 4.2 & 22 & 11.5 & 61 & 31.8 & 61 & 31.8 & 38 & 19.8 & 2 & 1.0 & 192 & 100 \\
\hline $\begin{array}{l}\text { 8. I ask myself questions about } \\
\text { the text }\end{array}$ & 17 & 8.9 & 24 & 12.5 & 54 & 28.1 & 52 & 27.1 & 45 & 23.4 & - & - & 192 & 100 \\
\hline $\begin{array}{l}\text { 9. I jump forward or backwards } \\
\text { in the text to find important } \\
\text { information }\end{array}$ & 38 & 19.8 & 28 & 14.6 & 32 & 16.7 & 48 & 25.0 & 46 & 24.0 & - & - & 192 & 100 \\
\hline $\begin{array}{l}\text { 10. I distinguish between } \\
\text { information that I already know } \\
\text { and new information }\end{array}$ & 4 & 2.1 & 10 & 5.2 & 41 & 21.4 & 57 & 29.7 & 78 & 40.6 & 2 & 1.0 & 192 & 100 \\
\hline $\begin{array}{l}\text { 11. I check whether I anticipate } \\
\text { information correctly }\end{array}$ & 15 & 7.8 & 25 & 13.0 & 58 & 30.2 & 70 & 36.5 & 23 & 12.0 & 1 & 0.5 & 192 & 100 \\
\hline $\begin{array}{l}\text { 12. I change my reading strategies } \\
\text { when I cannot comprehend } \\
\text { the text }\end{array}$ & 7 & 3.6 & 13 & 6.8 & 47 & 24.5 & 56 & 29.2 & 69 & 35.9 & - & - & 192 & 100 \\
\hline $\begin{array}{l}\text { 13. I try to underline when reading } \\
\text { in order to remember the text }\end{array}$ & 57 & 29.7 & 48 & 25.0 & 44 & 22.9 & 27 & 14.1 & 16 & 8.3 & - & - & 192 & 100 \\
\hline $\begin{array}{l}\text { 14. I read more than once in order } \\
\text { remember the text }\end{array}$ & 21 & 10.9 & 32 & 16.7 & 44 & 22.9 & 47 & 24.5 & 48 & 25.0 & - & - & 192 & 100 \\
\hline $\begin{array}{l}\text { 15. I make notes in order to } \\
\text { remember the text }\end{array}$ & 59 & 30.7 & 45 & 23.4 & 39 & 20.3 & 32 & 16.7 & 17 & 8.9 & - & - & 192 & 100 \\
\hline $\begin{array}{l}\text { 16. I try to visualise the } \\
\text { descriptions in the text }\end{array}$ & 16 & 8.3 & 19 & 9.9 & 41 & 21.4 & 59 & 30.7 & 56 & 29.2 & 1 & 0.5 & 192 & 100 \\
\hline $\begin{array}{l}\text { 17. I note what I am interested in } \\
\text { or bored by with in the text }\end{array}$ & 4 & 2.1 & 7 & 3.6 & 29 & 15.1 & 52 & 27.1 & 98 & 51.0 & 2 & 1.0 & 192 & 100 \\
\hline $\begin{array}{l}\text { 18. I try to anticipate information in } \\
\text { the text; I note how difficult or } \\
\text { easy a text is to read }\end{array}$ & 8 & 4.2 & 10 & 5.2 & 36 & 18.8 & 63 & 32.8 & 74 & 38.5 & 1 & 0.5 & 192 & 100.0 \\
\hline
\end{tabular}

$f$, frequency.

TABLE 3: Post-reading strategies.

\begin{tabular}{|c|c|c|c|c|c|c|c|c|c|c|c|c|c|c|}
\hline \multirow[t]{2}{*}{ Statement } & \multicolumn{2}{|c|}{$\begin{array}{l}\text { Never or } \\
\text { almost never } \\
\text { true for me }\end{array}$} & \multicolumn{2}{|c|}{$\begin{array}{l}\text { Usually not } \\
\text { true for me }\end{array}$} & \multicolumn{2}{|c|}{$\begin{array}{l}\text { Somewhat } \\
\text { true for me }\end{array}$} & \multicolumn{2}{|c|}{$\begin{array}{l}\text { Usually true } \\
\text { for me }\end{array}$} & \multicolumn{2}{|c|}{$\begin{array}{l}\text { Always true } \\
\text { for me }\end{array}$} & \multicolumn{2}{|c|}{ No response } & \multicolumn{2}{|c|}{ Total } \\
\hline & $f$ & $\%$ & $f$ & $\%$ & $f$ & $\%$ & $f$ & $\%$ & $f$ & $\%$ & $f$ & $\%$ & $f$ & $\%$ \\
\hline 1. I review the text & 23 & 12.0 & 41 & 21.4 & 47 & 24.5 & 41 & 21.4 & 38 & 19.8 & 2 & 1.0 & 192 & 100 \\
\hline 2. I summarise the text & 36 & 18.8 & 55 & 26.8 & 53 & 27.6 & 26 & 13.5 & 22 & 11.5 & & & 192 & 100 \\
\hline 3. I try to interpret what I have read & 24 & 12.5 & 28 & 14.6 & 66 & 34.4 & 42 & 21.9 & 31 & 16.1 & 1 & 0.5 & 192 & 100 \\
\hline 4. I evaluate the text & 15 & 7.8 & 35 & 18.2 & 72 & 37.5 & 49 & 25.5 & 21 & 10.9 & - & - & 192 & 100 \\
\hline $\begin{array}{l}\text { 6. I anticipate how I will use the } \\
\text { knowledge gained from reading }\end{array}$ & 11 & 5.7 & 23 & 12.0 & 48 & 25.0 & 79 & 41.1 & 31 & 16.1 & - & - & 192 & 100 \\
\hline $\begin{array}{l}\text { 7. I evaluate whether what I have } \\
\text { read is relevant to my reading } \\
\text { goals }\end{array}$ & 13 & 6.8 & 25 & 13.0 & 82 & 42.7 & 2 & 1.0 & 26.6 & 20 & 10.4 & - & 192 & 100 \\
\hline $\begin{array}{l}\text { 8. I vary my reading style depending } \\
\text { on my reading goals }\end{array}$ & 12 & 6.3 & 30 & 15.6 & 44 & 22.9 & 57 & 29.7 & 25.5 & - & - & - & 192 & 100 \\
\hline
\end{tabular}

$f$, frequency. 
TABLE 4a: The significant difference between the perceived strategies by learners and gender. (Question: When information is critical to my understanding of the text is no directly stated, I try to infer that information from the text.)

\begin{tabular}{|c|c|c|c|c|c|c|c|}
\hline Gender & $\begin{array}{l}\text { Never or almost } \\
\text { never true for me }\end{array}$ & $\begin{array}{l}\text { Usually not } \\
\text { true for me }\end{array}$ & $\begin{array}{l}\text { Somewhat } \\
\text { true for me }\end{array}$ & $\begin{array}{l}\text { Usually true } \\
\text { for me }\end{array}$ & $\begin{array}{l}\text { Always or almost } \\
\text { true for me }\end{array}$ & No response & Total \\
\hline \multicolumn{8}{|l|}{ Male } \\
\hline Count & 4 & 17 & 38 & 16 & 5 & 0 & 80 \\
\hline$\%$ within gender & 5 & 21.3 & 47.5 & 20 & 6.3 & 0 & 100 \\
\hline \multicolumn{8}{|l|}{ Female } \\
\hline Count & 14 & 19 & 32 & 34 & 12 & 1 & 112 \\
\hline$\%$ within gender & 12.5 & 17 & 28.6 & 30.4 & 10.7 & 0.9 & 100 \\
\hline Count & 18 & 36 & 70 & 50 & 17 & 1 & 192 \\
\hline$\%$ of total & 9.4 & 18.8 & 36.5 & 26 & 8.9 & 0.5 & 100 \\
\hline
\end{tabular}

TABLE 4b: Chi-Square tests.

\begin{tabular}{llll}
\hline Cross-tabulation test & Value & $d f$ & $\begin{array}{l}\text { Asymptotic } \\
\text { significance } \\
\text { (two-sided) }\end{array}$ \\
\hline Pearson Chi-square & 11.530 & 5 & 0.042 \\
Likelihood ratio & 12.136 & 5 & 0.033 \\
Number of valid cases & 192 & - & - \\
\hline
\end{tabular}

$d f$, degrees of freedom.

they have read or review, evaluate and interpret what they have read. These finding contradict the findings of a study conducted by Zhang and $\mathrm{Wu}$ (2009), who found that the majority of learners were conscious of the post-reading strategies they used and were able to utilise a wide range of English Foreign Language (EFL) post-reading strategies to achieve comprehension.

Table 4 reveals that there was only one perceived reading strategy that proved significantly different when crosstabulated with gender: 'when information is critical to my understanding of the text is not directly stated, I try to infer that information from the text'. This item had a Chi-square ( $P$-value) of 0.042 , which is less than 0.05 . Therefore, the researchers rejected the hypothesis that reading strategy use differed according to gender, since there was only one reading strategy that proved significantly different out of 34 reading strategies. Therefore, the researchers accepted the null hypothesis that girls do not have higher reading strategy use than boys.

Many studies have indicated that girls use a wider range of reading strategies than boys (Green \& Oxford 1995; Monos 2004; Young \& Oxford 1997). Such studies have also reported that since girls use a wider range of strategies than boys, they are better readers. For example, the results of a study conducted by Tsai et al. (2010) revealed that strategy use has a positive influence on reading proficiency because skilled readers use more strategies in various categories than lessskilled readers do. Therefore, the idea of examining gender differences in strategy use in this study was to close the gap, if there was any, in strategy use between girls and boys. With regard to gender versus perceived reading strategy use, the results of the current study indicated that there was only one reading strategy out of 34 that revealed a difference in strategy use between boys and girls. This strategy was most frequently used by girls. Therefore, the current study differs from most studies that suggest that girls read better than boys (Green \& Oxford 1995; Monos 2004; Young \& Oxford 1997) because there was little evidence that proved that boys used fewer reading strategies than girls. This finding is supported by Rutter et al. (2000), who state that girls are over-presented as gifted readers who use a wide range of strategies, although these differences are small.

\section{Conclusion and recommendations}

The main objective of the study was to investigate the reading strategies employed by learners from the selected school. The study also set out to discover if there was any significant difference between the perceived reading strategy use of boys and girls. By examining the learners' responses to the questionnaire, the study revealed that the Grade 9 learners from the selected school were not aware of and were not using a wide range of reading strategies. There were very few reading strategies that seemed to be popular to the learners in all categories. The study also revealed that there was no particular connection in the perceived strategy use of female and male learners, as only one strategy out of 34 strategies given indicated a significant difference when cross-tabulated with gender.

The findings of the study have some practical implications for ESL reading strategy instruction in schools in South Africa or other educational settings that share similar characteristics. The results indicated that the majority of learners were not using some reading strategies at all. This calls for educators to identify such reading strategies and teach the learners about why and how they are used in the reading process. In addition, teachers should provide strategy training integrated with normal language work to boost linguistic proficiency at the same time. In other words, the incorporation of explicit strategy training into the usual reading instruction procedures is recommended. It is hoped that learners will gradually develop a degree of autonomy in using these reading strategies in different contexts. Based on the findings of this study, teachers are strongly advised to administer the reading strategy questionnaires to their learners to identify the problem areas that might need attention in order to improve the reading comprehension of the learners.

Despite the fact that this study has revealed some interesting findings that might inform ESL reading instruction, it has a number of limitations that were highlighted under the explanation of the research method. For example, although 
in some instances learners claimed to be aware of and using certain reading strategies, it was difficult for the researchers to know whether learners were actually using those reading strategies. For future research it is recommended that reading comprehension tests, think-aloud protocols or interviews are included to further examine learners' actual strategy use.

\section{Acknowledgements Competing interests}

The authors declare that they have no financial or personal relationship(s) that may have inappropriately influenced them in writing this article.

\section{Authors' contributions}

M.C. (University of Fort Hare) wrote the first and final drafts of the article. N.M. (University of Fort Hare) collected and analysed the data and refined the final draft.

\section{References}

AD-Heisat, M.A., 2009, 'The use of reading strategies in developing students' reading competence among primary school teachers in Malaysia', European Journal of Social Sciences 2(1), 257-280.

Alhaqbani, A. \& Riazi, M., 2012, 'Metacognitive awareness of reading strategy use in Arabic as a second language', Reading in a Foreign Language 24(2), 231-255.

Al-Issa, A., 2006, 'Schema theory and L2 reading comprehension: Implications for teaching', Journal of College Teaching \& Learning 3(7), 41-47.

Begeny, J.C., Laugle, K.M., Krouse, H.E., Lynn, A.E., Tayrose, M.P. \& Stage, S.A., 2010, 'A control-group comparison of two reading fluency programs: The helping early literacy with practice strategies (HELPS) program and the great leaps $\mathrm{K}-2$ reading program', School Psychology Review 35, 91-107.

Berrett, S., 2011, 'The importance of pre-reading', in The reading corner, viewed 16 March 2013, from http://athome.readinghorizons.com/community/blog/ the-importance-of-pre-reading/

Carrell, P.L., 1989, 'Metacognitive strategy training for ESL reading', TESOL Quarterly 24(4), 647-678. http://dx.doi.org/10.2307/3587536

Cekiso, M.P., 2007, 'Evaluating reading strategies instruction', unpublished PhD dissertation, Department of English, North West University, Potchefstroom.

Cekiso, M., 2012, 'Reading comprehension and strategy awareness of Grade 11 English second language learners', Reading \& Writing 3(1), 1-8. http://dx.doi. org/10.4102/rw.v3i1.23

Christen, W.L. \& Murphy, T.J., 1991, Vocabulary instruction and reading comprehension, Grove Press, New York.

Dotwana, V.L., 2009, 'Reading strategies and reading ability of Grade eleven English Second Language learners', unpublished MEd dissertation, Walter Sisulu University, Mthatha.

Dreyer, C. \& Nel, C., 2003, 'Teaching reading strategies and reading comprehension within a technology and enhanced learning environment', Potchefstroom University, Potchefstroom.
Euerbach, E. \& Paxton, D., 1997, “It's not the English thing": Bringing reading research into the ESL classroom', TESOL Quarterly 32(2), 237-261. http://dx.doi. org/10.2307/3588046

Flowerdew, J. \& Peacock, M., 2001, 'The EAP curriculum: Issues, methods, and challenges', in J. Flowerdew \& M. Peacock (eds.), Research perspectives on English for academic purposes, pp. 177-194, Cambridge University Press, Cambridge. http://dx.doi.org/10.1017/СВ09781139524766.015

Grabe, W., 1991, 'Current developments in second language reading research', TESOL Quarterly 25(3), 375-406. http://dx.doi.org/10.2307/3586977

Green, J.M. \& Oxford, R.L., 1995, 'A closer look at learning strategies, L2 proficiency and gender', TESOL Quarterly 25(2), 261-297. http://dx.doi.org/10.2307/3587625

Jimenez, R.T., 1996, 'The reading strategies of bilingual Latina/o students who are successful English readers: Opportunities and obstacles', Reading Research Quarterly 31, 90-112. http://dx.doi.org/10.1598/RRQ.31.1.5

Madikiza, N., 2011, 'An investigation into reading strategies employed by Grade 9 learners at James Kobi JSS: Implications for teaching reading', unpublished MEd dissertation, Walter Sisulu University, Mthatha.

Maree, K., 2008, First steps in research, Van Schaik Publishers, Hatfield, Pretoria.

Mokhtari, K. \& Reichard, C., 2004, 'Investigating the strategic reading process of first and second language readers in two different cultural contexts', System 32, 379-394. http://dx.doi.org/10.1016/j.system.2004.04.005

Monos, K., 2004, Learner strategies of Hungarian secondary grammar school students, Akademiai Kiado, Budapest.

Noor, N.M., 2010, 'ESL learners' reading approaches of an academic expository text', The Southeast Asian Journal of English Language Studies 16(2), 61-75.

Oxford, R.L., 1990, Language learning strategies: What every teacher should know, Heinle and Heinle, Boston.

Poole, A., 2009, 'The reading strategies used by male and female Colombian university students', Profile Issues in Teachers' Professional Development 11(3), 1-11.

Porter, K., 2010, Pre-reading strategies, viewed 18 October 2012, from http://www. departments.webar.edu/teacher/reading/pre-reading.html

Pretorius, E.J., 2002, 'Reading and applied linguistics: A deafening silence?', Southern African Linguistics and Applied Language Studies 20, 91-103. http://dx.doi. org/10.2989/16073610209486300

Rutter, M., Caspi, A., Fergusson, D., Horwood, R.J., Goodman, R., Maughan, B. et al., 2000, 'Sex differences in development reading disability', Journal of the American Medical Association 291(16), 2007-2012. http://dx doi.org/10.1001/ jama.291.16.2007

Saricoban, A., 2002, 'Reading strategies of successful readers through the three phase approach', The Reading Matrix 2(3), 149-165.

Sheorey, R. \& Mokhtari, K., 2001, 'Differences in the metacognitive awareness of reading strategies among native and non-native readers', System 29, 431-449. http://dx.doi.org/10.1016/S0346-251X(01)00039-2

Tercanlioglu, L., 2004, 'Exploring gender effect on adult foreign language learning strategies', Issues in Educational Research 14(2), 8-17.

Tsai, Y., Ernest, C. \& Talley, P.C., 2010, L1 and L2 strategy use in reading comprehension of Chinese EFL readers, Routledge, I-Shou University, Taiwan.

Van Wyk, A.L., 2001, 'The development and implementation of an English language and literature learners', unpublished thesis, Department of English Language and Literature, University of the Free State, Bloemfontein.

Wessels, M., 2007, Practical guide to facilitating language learning, 2nd edn., Oxford University Press, South Africa.

Young, D.J. \& Oxford, R.L., 1997, 'A gender-related analysis of strategies used to process written input in the native language and a foreign language', Applied Language Learning 8(1), 43-73.

Zhang, L.J. \& Wu, A., 2009, 'Chinese senior high EFL students' metacognitive awareness and reading -strategy use', Reading in a Foreign Language 21(1), 37-59. 